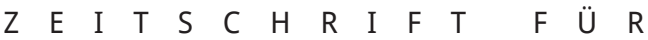

$\begin{array}{lllllllllllllllllllll}V & E & R & W & A & L & T & U & N & G & S & G & E & S & C & H & I & C & H & T & E\end{array}$

$\begin{array}{lllllllll}B & A & N & D & 3 & 2 & 0 & 1 & 8\end{array}$

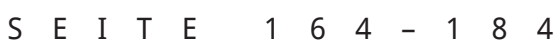

D O I : $10.2478 / \mathrm{ADH}$ I- $2018-0041$

\title{
The Bureaucracy of Honor. The Habsburg Consular Service and the History of Emotions
}

\author{
ALISON FRANK JOHNSON ${ }^{1}$
}

Mich schreckt kein Tod, als Mann zu handeln, Den Weg der Tugend fort zu wandeln.

Schliesst mir des Schreckens Pforten auf! ${ }^{2}$

Es ist meine Pflicht, ihm als Freund entgegenzutreten. ${ }^{3}$

\section{Introduction}

This is a story about bureaucratic storytelling, about civil servants whose impartiality and professionalism lay at the core of their self-identity and about the emotional richness of the records they kept about their professional lives. The protagonists served as consuls in the Habsburg Monarchy's large foreign service. The emotions were honor and, most particularly, the rage and astonishment that came after insult. The insults were slurs, slaps, scoldings - over cards, over a cab, over the use of Hungarian - over incidents that now seem trivial but were of mortal importance to the men in these stories. The stories in question explained the legitimacy of the outrage and the necessity of (occasionally lifethreatening) actions taken to restore equilibrium. The resolutions ranged from fully satisfactory to personally devastating. The evidence for these stories of insult and satisfaction comes entirely from the bureaucratic archives of the Austro-Hungarian Ministry of Foreign Affairs. Through these records, the storytellers transform one gentleman's personal embarrassment into the business of bureaucracy - a group project, that is, representing a shared commitment to protect the honor of the empire itself.

Around the turn of the twentieth century, AustriaHungary's Ministry of Foreign Affairs sent diplomats and consuls all over the world. Every consulate produced stack upon stack of paper. ${ }^{4}$ Thanks to what István Deák called »centuries of bureaucratic punctiliousness «, the paperwork sent back to Vienna was preserved in an archive. ${ }^{5}$ The management of paper was a core part of what made the bureaucrat a recognizable professional type: from the lowliest postal official to the emperor himself; the processing, organizing, producing, and distributing of paper lay at the heart of the management of empire. ${ }^{6}$ Countless boxes were sorted by place ("Yokohama $\star^{7}$ ), by subject matter (»Slave Trade $\left.\star^{8}\right)$, or by name (»Czerwenka, Waldemar»). Some consuls’ papers were spread out across the files of the various consular posts they held. Other consuls' files, however, were given their own folder in Fach 4, »Personalia«. 
That is the case of the three consuls whose stories are examined here. I read through their files for reasons unconnected to the subject of this essay - each of them had submitted a complaint about the Austrian Lloyd. ${ }^{9}$ I was curious about the consuls' credibility vis à vis the Lloyd, a private but publicly subsidized shipping company that was among the largest and most powerful corporations in the Habsburg monarchy. Could I learn more about the Lloyd by looking closely at the consuls who criticized it? Perhaps the consuls' personnel files would provide evidence of how reliable their supervisors considered their reports. I looked for evidence left by a rational bureaucracy - whom did the experts believe? What I found was evidence that the glue holding the consular corps together was not rational bureaucracy but a homosocial honor culture that repeatedly synthesized emotion into the language of dispassionate evaluation. Austria-Hungary's consular bureaucracy was a community created not only by training and purpose but also by feeling. ${ }^{10}$ But, those feelings were carefully circumscribed - certain feelings, in certain locations, and at certain times, were absolutely compatible with the professional decorum of the gentleman-bureaucrat and were, moreover, part of the consulate's business.

In some ways, the personnel files of Waldemar Czerwenka, Dominik Szathmáry Király, and Maximilian Kutschera are opaque and unrevealing, shorn of personal detail. The files are full of notifications of their arrival at or departure from various posts, acknowledgments of reassignments, requests for reimbursement of expenditures for professional purposes, permission to go on vacation or take leave for mandatory military training, complaints about local inflation and requests for pay raises, assessments of eligibility for promotions, requests to marry, and reviews of eligibility for pensions. Some of these are clearly professional - they involve the appropriate use of funds, the maintenance of necessary staffing levels, the functioning of the office, and the assessment of promotions and raises. Sometimes, they border on the very personal. Processing a lawyer's request to track down a consul's income for a paternity suit divulges more about the consul's past than he might wish. ${ }^{11}$ Processing a consul's request for permission to marry exposes more information to the historian than to the consul himself.
(Consuls likely did not know that the moral character and financial circumstances of their brides became the subjects of "discrete" police investigation. ${ }^{12}$ ). But, not one of these files is professionally irrelevant. Marriage was discouraged because consuls had to be constantly mobile; absences affected the functioning of the offices; illnesses might endanger the suitability of the consul for future employment. Everything in these files is there because of its relevance to the management of the consular service and not because of its value in recreating the personalities of the consuls themselves. When an engagement was called off, there was no speculation about the cause, no expression of regret at a heart possibly broken (his? hers?). ${ }^{13}$ Such musings would be out of place in the records of the bureaucracy of masculine respectability.

Yet, despite their ostensible commitment to professionalism and dispassionate reporting of their daily business, the files also offer glimpses of the emotional lives of men in the consular service - the consuls and their colleagues and supervisors. They show, at times, the emotional resonance of the spirit of solidarity that emerged from the common commitment to the consular corps. Consuls were expected to be impartial in their treatment of Habsburg subjects abroad who required their support, intervention, or service; they were expected to embody standards uninflected by emotional engagement. Superiors treated transgressions severely, yet consuls could call on one another's empathy and support when their misbehaviors were considered understandable responses to emotional challenges they faced in the field. When a consul's honor was insulted, for example, his colleagues rushed to support his attempts to gain satisfaction. These files doubly undermine the notion of bureaucracy as dry and rational - first by acknowledging consuls' emotional responses to personal challenges and second by marshaling the bureaucracy's resources to respond to those challenges. In other words, they blur the boundaries not only between the consul's personal and professional lives but also between one man's private affairs and the bureaucracy's business.

It is tempting to think of honor - especially the honor of a nineteenth century European sgentleman' as the most personal of attributes. It speaks to a man's outer bearing and his innermost worth. "Honour ", Ute Frevert 
has written, is "an emotional disposition focusing on a person's moral and physical integrity «. ${ }^{14}$ What could be more personal, more individual, than "moral and physical integrity «? ${ }^{15}$ One might thus expect individual honor to have no place in an advanced, modern bureaucracy. "Bureaucracy», Patrick Joyce explains, "depends on the extinction of the individual personality of the bureaucrat and its replacement by what is designed to be regarded as the neutral, and therefore, autonomous, personhood of the bureaucrat «. ${ }^{16}$ The nineteenth century German jurist Rudolf von Jhering remarked on the same phenomenon in anguish, perhaps even disgust, when he contrasted the rights of people of "especially high birth « and even "officers « to defend with violence insults to their honor against the expectation that "civil servants (Staatsbeamten) cannot be afforded the same«. This state of affairs threatened, according to Jhering, to make of Germany a "society of moral eunuchs «. ${ }^{17}$ In each of these cases, personnel in the consulate and in the Ministry of Foreign Affairs cooperated to defend the "moral and physical integrity" of an "individual personality" by making his honor their business. A consul's ability to defend his honor, far from being extinguished by his professional obligations to the bureaucracy, was promoted by it. ${ }^{18}$

Each of these cases involved the bureaucratic processing of a man's - and indeed an entire consulate's response to an insult made while the consul himself was >off-duty`. Insult, like marriage or mental health, was a matter of professional relevance. A consul's honor, to borrow a phrase from Ute Frevert, was "a professional asset of crucial importance ${ }^{19}$ Bureaucrats recorded, in the administrative record, their response to threats to the honor of a consul, even if those threats took place outside the consulate itself. The necessity of demanding satisfaction (Satisfaktion) was part of that response. Satisfaction implied an obligation to be willing to break the law in order to remain professionally relevant and personally honorable. ${ }^{20}$

In reading these files, I was struck by the juxtaposition between the emotionally familiar and the emotionally foreign. Historians are trained to expect emotions to be variable across time. The consuls' files show a concern with honor and ideas about the appropriate ways to respond to insult that are hard to relate to today. be more precise, a disposition whose emotional power has more or less vanished «. ${ }^{21}$ These documents were composed at a time when their readers counted honor among the "most noteworthy emotions«.22 Frevert, Julian Pitt-Rivers, Frank Henderson Stewart, and others have defined honor at length, in multiple studies. ${ }^{23}$ As Henderson Stewart has discussed, at the heart of most of these definitions is some recognition that honor implies both an internal and an external element. ${ }^{24}$ Henderson concludes that honor is a "claim-right", that is, the right of a bearer, who has certain qualities that entitle him (in the case of the gendered male honor under discussion in these cases) to respect, to claim from the world that he be treated with the respect he deserves. ${ }^{25}$ Since these consuls were officers in the Austro-Hungarian military, they were considered, in Kwame Appiah's words, to be people "of the right station" who knew how to "keep the codes" of their "honor world «. ${ }^{26}$ The phrase "honor world" raises the question of the relevance of William Reddy's concept of the emotional "regime«, which he defines as »The set of normative emotions and the official rituals, practices, and semotives that express and inculcate them; a necessary underpinning of any stable political regime«. ${ }^{27}$ "Style«, he continues, "becomes sregime` when the sum of the penalties and exclusions adds up to a coherent structure, and the issue of conformity becomes defining for the individual«. ${ }^{28}$ The consuls' emotional regime was maintained not only through negative consequences - shame and decommissioning (for officers) for failing to uphold one's honor - but also by what amounted to informal state subventions for those who did conform.

I am, however, also struck by the limits to this nearly unimaginable world of honor obsession - that is, by the traces of a very easily imaginable reluctance to die over a few words uttered in irritation over a game of cards. The consuls were willing to risk their lives to protect their honor. But they were not indifferent to life or death; this is where their peers in the consulate played such a critical role. "It is neither the bullet nor the sword that kill«, noted the infamous nineteenth century wit, Alphonse Karr, »it is the seconds! «29 A duel that took place was the result of the failure of the seconds to propose, persuasively, an alternative method of providing the insulted party with ssatisfaction،. These three cases provide an example of how such a 
sfailure - and the resultant duel - could be justified to governmental authorities who knew very well that dueling was illegal. They also show examples of how consuls had a different notion of what was required to maintain their honor than, say, journalists. Affairs of honor - wounded feelings, volatile tempers, endangered lives - both penetrated and repurposed the bureaucracy's administrative apparatus.

Austro-Hungarian consuls belonged to two different, overlapping "honor worlds", each with its own codes of conduct. Piskur's Consularwesen and Malfatti's Handbuch des österreichisch-ungarischen Konsularwesens, in multiple editions, laid out regulations and expectations. Consuls, however, were also often reserve officers and had a responsibility to protect the corporate honor of the officer corps. ${ }^{30}$ After the new military law of 1868 introduced universal conscription, a graduate of the Consular Academy could only get an attaché post, or Elevenstelle, once he had completed service as a "oneyear volunteer « or Einjährig-Freiwilliger. ${ }^{31}$ Completing this year of service also entitled him to sit for an examination that, if passed, allowed him to become a lieutenant in the reserve. ${ }^{32}$ Both Szathmáry Király and Czerwenka were reserve lieutenants in the army; Kutschera had served as a full-time lieutenant in the navy. As civil servants, consuls knew how to consult instruction manuals. Nineteenth century publications about honor and dueling codified strict expectations for maintaining honor and horrible consequences for losing it. According to Frank Stewart Henderson, »the most intensive and sophisticated discussion of honor in any European language is probably to be found in the writings of the German lawyers during the nineteenth and twentieth centuries «. ${ }^{33}$ Dueling codes laid out in great detail how that was to be done - and represent, borrowing a phrase from Stearns, documents establishing the "emotionology " of the officer corps. ${ }^{34}$

The officer's social pressure to demand satisfaction when insulted and to accept a challenge, if offered, was documented in literature, in the press, in military personnel files. There is no doubt that a man of honor who refused to respond with the appropriate degree of outrage to an insult put his career at risk. ${ }^{35}$ That is the world in which these three consuls, Czerwenka, Szathmáry Király, and Kutschera, lived and worked. discipline around the maintenance of honor, however, but also helped them meet expectations and preserve honor. The files, that is, record not simply the honor of individual bureaucratic functionaries but honor as a function of bureaucracy.

The openness with which consular officials reported that they had recommended dueling to their subordinates, served as seconds, helped to arrange duels, overseen the production of srules of engagement for duels, and warned their subordinates of the consequences of not dueling is revealing. Dueling in Austria, remember, was illegal according to civilian and military law. ${ }^{36}$ Leo XIII issued an encyclical addressed to the "Archbishops and Bishops of the German Empire and Austria-Hungary « condemning dueling. ${ }^{37}$ Yet, even men who regarded dueling as barbaric and antiquated still felt the need to demand "Satisfaktion" in order to prove they were not cowards. Renowned socialists dueled to defend their masculine honor. ${ }^{38}$ The AntiDueling League condoned some duels even as it strove to reduce their number; it should really have been called the Anti-Frivolous-Dueling League. ${ }^{39}$ A 1908 New York Times article lamented the fact that a diplomat stationed in Central Europe who refused to duel became a coward even in the eyes of people who found dueling childish, anachronistic, and barbaric. ${ }^{40}$ Faced with the choice of losing a diplomatic post over breaking the law and "foreit[ing] whatever social standing and prestige he may have previously had in his own country" as a result of his cowardice, the author concluded that "it is better to fight, even at the risk of dismissal from the diplomatic service ${ }^{41}$ One Austro-Hungarian officer who attempted to refuse to duel on conscientious grounds in 1900 was stripped of his commission because, a court of honor concluded, he "had wounded the honor of the corps by avoiding a duel through the citation of inane pretexts and unjustified preconditions «. ${ }^{42}$ Dueling undeniably came with a cost - but the cost of not dueling sometimes seemed greater. ${ }^{43}$

Wherever they traveled, Austro-Hungarian consuls brought this honor world with them. In 1904, there were 493 Austro-Hungarian consulates, with locations on every inhabited continent. ${ }^{44}$ Consulates were "public government agencies" responsible for »representing foreign trade and shipping interests abroad, protecting Austrian nationals abroad, and supervising, promoting, 
and strengthening the international relations of the imperial state by means of orderly official activity at the most important commercial locations « ${ }^{45}$ Consulates served the needs of individual expatriates in distress but were primarily intended to cultivate trade and serve domestic interests; consuls, although frequently transferred from one post to another, were expected to develop specific expertise in each geographic area where they were stationed. ${ }^{46}$ Unlike high-ranking diplomats, who were often chosen on the basis of family connections, they had the biographies and family backgrounds of typical mid-rank civil servants. ${ }^{47}$

Most consuls were highly educated. ${ }^{48}$ They were, at a minimum, expected to be familiar with law, domestic and international politics, and the principles of business administration. They were required to be proficient in German, Italian, French, and a variety of other languages. "Spotless moral character» was expected, although Deusch's compendium of biographies makes clear that spotlessness, like honor, was a difficult matter for bureaucrats to judge ${ }^{49}$ There were periodic complaints that the consuls' education was shallow, their knowledge of foreign language superficial, their fluency in codes of conduct and social mores inadequate and that they needed more "social education " and "instruction in propriety «. ${ }^{50}$ These complaints emphasize how much was expected of the role - »exact knowledge of the fatherland's own institutions, laws, and governing principles as well as of the needs of Austrian commerce and trade«, not to mention specialized expertise and local language based on the assignment, all this on top of the "general professional qualifications for state service.$^{51}$

Expertise, however, was no substitute for high birth, and, as in other European empires, consuls did not enjoy the status of diplomats or aristocrats. ${ }^{52}$ They were chosen not to stand out for personal excellence but to blend in to a bureaucracy of reliability and competence.

By the late nineteenth century, European powers like the Habsburg Monarchy had highly developed bureaucracies staffed by career civil servants. True to type, consular officials were expected to be competent and impartial, in Max Weber's oft-quoted formulation, "functionaries who have specialized training and who by constant practice increase their expertise «.53 The behavior towards all" and "strict impartiality" as two of the consul's foundational duties. ${ }^{54}$ Habsburg consuls were bureaucrats, and their correspondence and records were meticulously preserved in reports to the Ministry of Foreign Affairs in Vienna. These documents were numbered, and stamped, and filed away. Indeed, the very production of this paperwork - the "labour of opening, reading, docketing, drafting, writing, copying, filing, and posting letters«, in David Vincent's words - was constitutive of the bureaucracy's "rationality“ itself. ${ }^{55}$ As Patrick Joyce has explained, "bureaucrats as well as the institution of bureaucracy were produced through the routines and material practices of bureaucratic work ". ${ }^{56}$ Consuls submitted receipts, noted comings and goings, and recorded promotions and reassignments. They submitted reports on economic opportunities, exports, and imports. Mountains of paper became monuments to impartiality and rationality. When consuls were evaluated, they were praised for being »eminently useful « ${ }^{57}$ (vorzüglich verwendbar) or displaying »exquisite official usability «58 (vorzügliche dienstliche Verwendbarkeit), which turned usefulness, serviceability or suitability for work into an accolade.

But consular officials were not automatons. As representatives of the imperial-royal government, they had to be dispassionate, yes, but they were also expected to use discretion, to care for their charges with feeling. As not only radvisors, protectors, and intermediaries', but in some countries also judges for Austrian and Hungarian nationals, they represented the ImperialRoyal government. "Their important position", the author of an 1862 manual on the Austrian Consular Service explained, "as discriminating correspondents [einsichtsvoller Berichterstatter] and as intellectually agile [geistig lebendiges] agents of state power « required "peculiar" forms of "preparation ". ${ }^{59}$ Consuls were the government's eyes and ears abroad - they needed to observe carefully, with sensitivity, and report back to Vienna on what they had seen. They needed to anticipate commercial opportunities and obstacles and to respond to Habsburg subjects' needs with discretion. They were not only calm, cool, collected, but also quick-witted ("geistig lebendig"). In mid-century Britain, there was some pushback against the idea that "expertise" was enough to make a good representative: "Brilliant talent 
and great acquirements are far less useful than moral qualities, in the holders of permanent offices «, wrote Early Grey in $1855 . .^{60}$ Those moral qualities reflected on the individual and the office he held. Habsburg consuls were proud - of their own standing, of their emperor - but also respectful, even of the most modest subjects entrusted to their care. "The consular official, and especially the head of an office, is obligated to protect the prestige of the imperial government and the Austrian name, as well as to conform externally through his tactful bearing as well as his dignified, respectable behavior, both on and off-duty, to the position accorded him « ${ }^{61}$ For a consul who took this charge seriously, his personal standing and the prestige of the empire itself were intertwined.

\section{Dominik Szathmáry Király ${ }^{62}$}

The archival record leaves little doubt: Dominik Szathmáry Király was a difficult man. One superior complained about his "headstrong and disagreeable disposition « ${ }^{63} \mathrm{He}$ fought in at least two duels, ${ }^{64}$ his superiors confidentially requested his transfer at least twice ${ }^{65}$ he was the subject of at least three civilian complaints for discriminatory and unprofessional behavior, ${ }^{66}$ he was transferred once as part of a disciplinary proceeding, ${ }^{67}$ and he was once sent to the tropics to replace a man who had died of yellow fever - one can only speculate about the hoped-for outcome of that assignment. The head of a legation in a country where he served as general consul noted with despair that he "was duty bound to consider him a friend and not an enemy « but found the task exceedingly difficult. ${ }^{68}$ Yet, his promotions continued apace. It seems likely that most of the men who worked with Szathmáry Király did not like him. It is nevertheless possible to distinguish clearly between those bouts of anger that his peers understood and defended, and those that left their brows furrowed. Szathmáry Király's case demonstrates clearly that there was considerable sympathy for - or at least tolerance and enabling of - a consul's emotional volatility under certain circumstances but that channeling those emotions in approved ways was a critical component of professional, that is, bureaucratic, competence.
In February 1886, Szathmáry Király was still a young man - just barely 29 and not quite six years into his service in the consular corps. He was a reserve lieutenant and a vice consul with experience in Trieste, Shkodër (Scutari, Albania), and Pljevlja (Montenegro) behind him and had been serving in Galați, Romania, for three years. One cold winter morning, Szathmáry Király was approached in his office by Robert Matsek, a reserve corporal (Unterjäger, the lowest rank of Unteroffizier, or non-commissioned officer [NCO]) who was traveling abroad as the mechanical assistant of a panorama owner and needed to report his presence in the area. When Szathmáry Király had trouble finding the relevant stamp in Matsek's military pass, Matsek reached across the vice consul's desk ${ }^{69}$ to show him the correct page. Szathmáry Király reprimanded Matsek for gesticulating "directly under [his] nose« and told him to stand at attention. Although Szathmáry Király was a reserve lieutenant and Matsek a reserve NCO, this interaction occurred in civilian attire, while neither man was on active duty. Matsek refused to take orders from Szathmáry Király. Their conversation became ever more heated until Szathmáry Király slapped Matsek twice and ordered guards to remove him from the consulate. Matsek filed a complaint, first in person with the consul general, who tried to make peace between the two men, and then formally in writing. The consulate conducted an investigation during which Szathmáry Király, Matsek, and the panorama owner (as a witness) provided sworn testimony.

Szathmáry Király's own statement regarding his altercation with Matsek concedes his heightened state of emotional agitation. Even after Matsek reached "under [his] nose« (unter meiner Nase ${ }^{70}$ ) toward his military pass, Szathmáry Király spoke »in a calm tone« (im ruhigen Tone), whereas, he reported, Matsek spoke in "an animated tone" (in animirten Tone) and in a "defiant manner" (trotziger Weise). As Matsek become "more agitated « (erregt), Szathmáry Király confessed that he "also became agitated" (ich bin auch erregt worden) and even indignant (ungehalten). Szathmáry Király's demand that Matsek stand at attention left the latter "beside himself with rage» (ganz außer sich zu bringen). Then came the critical moment for Szathmáry Király. Matsek "stamped with his feet on the ground and gesticulated with his hands, as one commonly 
does in order to emphasize something one has said through gestures«. Although Szathmáry Király could later describe these hand gestures as »common", in the moment, they enraged him. »This behavior of the man caused me to lose my composure and I screamed at him, ,You, if you continue with this, I don't know what I'll do, if you keep up this shameless behavior, you'll get slapped «

This, predictably did not help Matsek regain his own composure, and as he stamped and banged on the table, Szathmáry Király confessed, he "was carried away by a surge of emotion and slapped him twice in quick succession " (ließ mich in meiner Aufwallung hinreißen, demselben rasch zwei Ohrfeigen zu versetzen). It did not take long for Szathmáry Király to regain his lost composure; he calmed down as Matsek tussled with the guard sent to expel him from the consulate. Szathmáry Király, a native speaker of Hungarian himself, heard Matsek speaking Hungarian and "realizing that I had insulted the man «, he politely invited Matsek back into the office, this time switching from German to their shared language in order to appear more sympathetic. Matsek, however, did not deign to acknowledge their common tongue and replied "roughly" in German that he would not come in. Szathmáry Király knew he was wrong to "assault the man physically" and reported his mistake to his superior in the consulate. In the written report that he submitted as part of the disciplinary inquiry, he noted, "I sincerely regret that I wronged Matsek and insulted him; but I regret still more - and beg you to permit me to express my genuine feelings in this regard - that through this incident I injured the esteem and dignity of my office.$^{71}$

In evaluating his misconduct, the Commission noted as aggravating the fact that Szathmáry Király had carried out the misdeed "in office and while performing his official duties«. As mitigating, however, the Commission considered Szathmáry Király’s »agitation « (Aufregung), his »violent emotions" (heftige Gemüthsbewegung) and his sincere regret. ${ }^{72}$ The consular commission's investigation was reviewed by Department 10 in Vienna, which concluded that »Szathmáry’s [sic] behavior did not involve anything exactly dishonorable, but nevertheless, the coarse, nearly brutal conduct of this consular official towards one of his wards (Schutzbefohlene) does not allow to share a view of "gentlemanly « behavior that had taken hold in Britain: the gentleman "endureth all things, keeps [his] temper, and keeps [his] tongue «. ${ }^{74}$ Szathmáry Király's agitation was understandable, but it was also unprofessional. Since Matsek was not satisfaktionsfähig, there was no appropriate outlet for Szathmáry Király’s anger. He could not demand satisfaction, so he could receive none. Unsatisfied, he had acted on the principle of "Ehrennotwehr" - but a more appropriate way to have protected the dignity of his office would have been to treat Matsek with paternal severity but without physical engagement. The disciplinary panel in Vienna agreed that Szathmáry Király was at fault and disciplined him with relocation to a different consulate at the same pay. Since his relocation was a punishment, he was not entitled to the subsidies of moving costs that normally were provided.

Szathmáry Király's disciplinary transfer to Bucharest, if it taught him anything, did not teach him how to control his feelings. Nor was that really what he was expected to do. Szathmáry Király's transfer might lead one to believe the Habsburg foreign service held true to the expectation, apparently prevalent in Britain, that a gentleman "avoids what the French call scenes occasions of exhibition, in which the vulgar delight. He of course has feelings, but he never exhibits any to the world «. ${ }^{75}$ Easier said than done. Less than a year after the incident with Matsek, Szathmáry Király’s sviolent feelings this time, they rushed to his aid. It was 6 January 1887, the day before Szathmáry Király's $30^{\text {th }}$ birthday. He was returning to Bucharest by train, in civilian dress. (Although consuls were entitled to wear uniforms, with ribbons and buttons and trim all regulated as carefully as military uniforms, they were not regularly required to wear them. ${ }^{76}$ ) Upon his arrival at the Bucharest North Station, Szathmáry Király gave a porter his handbag and the claim check for his luggage. The porter placed Szathmáry Király's handbag in a cab (Fiaker) and went to retrieve the rest of his luggage. At the same time, a Romanian officer, whose uniform identified him as a Dorobanti Major in the Royal Romanian Army, came from the train, exchanged a few words with the porter as they passed in the hall, and then went to the wagon sreserved for Szathmáry Király and tossed the latter's handbag on the ground (in den Koth). 
Szathmáry Király approached the wagon and said, in French, "Pardon, Monsieur, this wagon has been occupied for me, as you saw «. ${ }^{77}$ The officer replied, in Romanian, that the wagon was not already "occupied « and that he himself occupied it, a statement he made factually incontrovertible by climbing into the wagon as he spoke. "Very unpleasantly affected (betroffen) by the officer’s behavior «, Szathmáry Király demanded, repeatedly and insistently (wiederholt und eindringlich), that the major acknowledge his claim to the wagon. The major screamed (according to Szathmáry Király), alternating between Romanian and French, that Szathmáry Király was a barbarian and (all interviewed witnesses agreed) punched him in the face, which "immediately caused his upper lip to swell«. Szathmáry Király countered (ripostirte) with his umbrella. The major called for the gendarmerie, and Szathmáry Király felt himself pulled backward from behind; his hat tumbled to the ground (in den Koth). At the same moment, a porter, who recognized Szathmáry Király, "crossed himself « and called out: "For God's sake, what have you done, that's the Austrian [sic] Vice Consul! «78 The gendarme immediately released Szathmáry Király. ${ }^{79}$

Free to move, Szathmáry Király approached the wagon and said to the major, again in French, "Monsieur, you owe me satisfaction, I ask that you give me your name«. The major replied, "I will not give you satisfaction, I will not tell you my name«.80 Szathmáry Király offered his calling card, while saying "But, Monsieur, you heard that I am the Austrian [sic] vice consul, here is my card «. The major refused to take the card. Szathmáry Király laid the card in his lap, repeating "you will give me satisfaction, tell me your name«. The major said not a word. At this point, according to his own telling, Szathmáry Király was »beside« himself (»ich war hierüber außer mir«) and looked in all directions for a witness to this travesty. He saw two Romanian officers three or four steps away, and turned to them saying, "Pardon, Messieurs, you are witnesses that this gentleman (Monsieur) refuses to give me satisfaction and to tell me his name«. One of the officers replied, in Romanian, "nu cunoştim «, (we do not know) and they turned away. When Szathmáry Király turned back to the wagon, he saw the major ride away, exclaiming to the police as he departed the station: "I
Király then stepped into another wagon that had been procured he knew not whence and rode into town. As was his duty (unerläßliche Pflicht), he reported the incident immediately in person and followed up with a written report the next day. Such a breach of protocol by a representative of the state required a full and open confession.

Yet, it turns out that the protocols in question were not those governing the behavior of civil servants but those stipulating the responsibilities and prerogatives of gentlemen. Karl Heidler Freiherr (Baron) von Egeregg, the chargé d'affaires and highest-ranking diplomat in the Austro-Hungarian legation in Bucharest, provided Szathmáry Király every imaginable assistance in his effort to secure satisfaction. Heidler personally approached the Romanian Minister of War to uncover the identity of the renegade major. The minister not only provided his name - Major Lazaresco - but placed him in arrest within his garrison. At Heidler's insistence, Szathmáry Király chose as his seconds Consul General Alexander Ritter von Suzzara and a Romanian who "belonged to the first society locally «. ${ }^{81}$ These two convinced Lazaresco of the necessity of a duel with relatively severe terms (Lazaresco's seconds suggested swords, and they insisted on pistols; Lazaresco's seconds suggested one shot at 40 paces, and they demanded two shots at 25 paces). ${ }^{82}$ The men met at the racetrack at 9 in the morning on 8 January. Both survived. Immediately following the duel, the seconds confirmed that "honor had been satisfied", and the two duelists "shook hands and embraced (umarmt) «. ${ }^{83}$ Major Lazaresco explained that the insult had been directed "not at the imperial royal vice consul and reserve officer Mr. von Szathmáry, whom he did not even know, but at an utterly unfamiliar person «. ${ }^{84}$ Where there had been disrespect, even deathly enmity, there was now a "fraternal bond " exactly what the rigorously ritualized structure of the duel was supposed to accomplish. ${ }^{85}$

This case generated dozens and dozens of pages of documents, now preserved in the Haus-, Hof- und Staatsarchiv. Heidler sent a report about the incident to Vienna with six attachments: a) the seconds' documentation of the rules of engagement for a planned duel to resolve the matter; b) the seconds' official report after the duel occurred; c) a statement made by the omnibus driver, a witness; $d$ ) the result of 
an investigation by another employee of the consulate; e) the general consul's description of the duel; and f) Szathmáry Király's report. Then, there were telegrams, inquiries, responses, and explanations - nearly 60 pages in all. It was a matter that required the attention of the entire leadership of the legation and supervisors back in Vienna. The open issue was not to manage diplomatic relations with Romania - Romanian authorities had eagerly assisted by identifying and arresting the major and even the gendarme who had grabbed Szathmáry Király by the collar - but rather to safeguard Szathmáry Király's honor. Both states shared an understanding of who had violated a code of conduct that was, from their perspective, universal in its applicability to gentlemen. In the general consul's words, »it was our unanimous opinion that the matter called for, indeed, in consideration of Mr. von Szathmáry's character as an officer as well as the violent nature of the insult, absolutely required, a resolution with weapons". That such a resolution was illegal did not make its open discussion in the Ministry's records any less advisable.

In the voluminous official correspondence about Szathmáry Király’s dispute with Lazaresco, attention repeatedly turns to the former's emotional state. Unlike following the incident with Matsek, Szathmáry Király's agitation was treated with empathy and understanding rather than criticism and discipline. Szathmáry Király himself confessed that he was »very unpleasantly affected " (sehr unangenehm betroffen) by the major's initial refusal to leave the carriage; "I was beside myself" (außer mir), he wrote, when the major refused to state his name and accept Szathmáry Király’s challenge. Heidler was pleased to report that "from the moment of the challenge on, the behavior of both Mr. v. Szathmáry and Major Lazaresco and his seconds was completely correct and in every way exemplary“. Szathmáry Király received the satisfaction he demanded - not only through the duel but also through the apology that Lazaresco offered, as honor required, only after he had stood and taken the shots aimed in his direction. ${ }^{86}$

The resolution of this incident was thus entirely satisfactory. Consul General Suzzara declared after the duel that "Mr. von Száthmary’s honor is, once again, spotless $«{ }^{87}$ The ritualized violence of the duel had the opposite effect of the impetuous violence Szathmáry Király had displayed against Matsek in Galați. ${ }^{88}$ In
Bucharest, both men 'won ‘ the moment they appeared; as Ute Frevert has explained, "the point was not to kill one's opponent, but to prove one's own courage by showing up «. ${ }^{89}$ It was not, however, only satisfactory because Szathmáry Király behaved well or because the major eventually responded honorably, or because the person whom the major had dared insult had not been a Habsburg consul or a lieutenant in the reserve but rather only a sstranger`, although all that helped. It was also satisfactory because it resolved the emotional needs of the participants. Suzzara had initially considered the emotional damage so great that he felt that Szathmáry should be transferred since "the sight of every Romanian officer will involuntarily remind him of the physical insult «. After the duel, however, Heidler explained that Suzzara had made this recommendation only in consideration of Szathmáry Király's earlier "great agitation « but that since the duel, "the desirable pacification has taken hold « and Szathmáry Király was once again »eminently professionally useful«. In order to function as a consul, Szathmáry Király had to receive satisfaction. It was a question not only of personal honor but also of the emotional stability required for bureaucratic competence.

Szathmáry Király’s colleagues provided him with countless forms of support. He himself had been unable even to ascertain the name of the man who had insulted him; Heidler used his professional connections to identify the assailant. He had been unable to persuade Lazaresco to accept his challenge; his seconds quickly and efficiently scheduled a duel under conditions that would give it a "serious character, if not the murderous one that Mr. von Száthmary [sic] himself had desired «..$^{90}$

The extent to which Szathmáry Király peers rallied to his defense is, at first blush, surprising. It is, after all, the threat of losing one's honor in the opinion of one's peers that makes demanding satisfaction so important. In Ute Frevert's words, "Violating [a man of honor's] integrity brought disgrace on the person who had been offended. Above all, it meant lowering and shaming him in front of an audience of peers. Those peers were concerned about the offence and demanded a vigorous reaction. A man who failed to react in an appropriate way, who shied away from calling the offender to account, was judged a coward «. ${ }^{91}$ Given the emphasis on honor as an essential characteristic of an individual, 
one might expect that the other men in the consulate would be a passive audience - waiting to see how the offended consul would respond, ready to judge him against their standard for honorable behavior. Yet, the response in this case seems less an individual action than a careful social negotiation. In Szathmáry Király's case, his peers became directly involved as his helpmates, and this applied not only to his seconds - a support role understood as critically necessary within the ritual of the duel - but also to the head of the AustroHungarian legation in Romania and his supervisors in Vienna. All this support was available for a man who had already been reprimanded for not being able to control his temper. Just as the honor of AustriaHungary and its emissary were indistinguishable in the person of Szathmáry Király, the homosocial network of brokers and seconds who regulated and oversaw the socially acceptable channeling of masculine anger was indistinguishable from the imperial bureaucracy itself. For all concerned, Satisfaktion was the only means of restoring personal and imperial equilibrium.

\section{Waldemar Czerwenka ${ }^{92}$}

Waldemar Roderich Czerwenka was in many ways Szathmáry Király's opposite. A successful and highly competent consular official, he was recognized by his superiors for "precision, conscientiousness, and factual solidity «- a model bureaucrat. His route to the relatively comfortable status of consul, a title he obtained in 1912 at age 32 , began with education, not birth. ${ }^{93}$

The son of a sawmill factory manager, Waldemar Czerwenka attended a German-language school in Czernowitz; graduated from the Consular Academy in Vienna; and entered the consular service on 15 October 1904, when he was 24 years old. ${ }^{94} \mathrm{He}$ was immediately assigned to the General Consulate in Shanghai with a salary of 6000 crowns a year and arrived there in late January $1905 .{ }^{95}$ At the same time, he was granted a commission as a reserve lieutenant in the $15^{\text {th }}$ Dragoner Regiment. A little over a year later, Czerwenka reported his first cause of dissatisfaction with his situation in Shanghai. His salary was set in Austrian Crowns (on the gold standard), but the local economy functioned using silver, and the Mexican »dollar" (or peso). Czerwenka's monthly payments (in tael) fluctuated according to the value of silver to gold. As the "youngest official, who has to make do with the smallest remuneration", he had seen the monthly payments he received in tael decline over his year of service, even though his salary in Crowns had risen from K517.01 to K571.12. The situation had reached a crisis where his "earnings ha[d] reached the level of a craftsman or worker « which led to the "absolute impossibility of living according to [his] station (standgemäss) «. ${ }^{96}$

Other records in Czerwenka's file provide insight into what exactly the young consular attaché thought "living according to his station" required. Czerwenka was 25, unmarried (although he had already been accused of fathering an illegitimate child, back in Vienna), and needed a respite from the maladies that had afflicted him since his arrival in Shanghai. He played bridge in the Shanghai Club nearly every day. ${ }^{97}$ The Shanghai Club, "the centre of the business and social life of the Settlement ${ }^{98}$, was a primarily British social club on the "Bund «, the most prestigious street in Shanghai's International Settlement. ${ }^{99}$ By joining the Shanghai Club, Czerwenka showed a conviction that his profession allowed his social position to float far above his disposable income. His contemporary, Otto Friedländer, half jestingly referred to such sensibility as snobbish: "An official belongs without doubt to the ruling class. Even if an official is poor, he needn't be ashamed, poverty is only honorable for officials«.100 But he also showed that he understood what Patrick Joyce has called "the extra-office environment" of the civil servant, especially those who, like consuls, were stationed abroad where they were "on display«. This display of European cultural superiority required $» \mathrm{a}$ peculiarly intense training in social etiquette, which was in practice a regulatory technology " in which a new arrival like Czerwenka was "actively mentored by superiors as he encountered the social life of the club«. Austria-Hungary's small "colony« of expatriate merchants in Shanghai hardly compares with the network of British bureaucrats stationed in India, but Joyce's observation that »in India, far from the personal life of the officer being rigidly separated from the job, as one part of the logic of the public servant would suggest, it was an active part of it« nevertheless sheds 
light on the professional importance of Czerwenka's gentlemanly comportment at the Shanghai Club. ${ }^{101}$

At the card table, Czerwenka often encountered another Austrian, Theodore Bume, who, according to Czerwenka's colleague in the consulate, was generally known for his "loud and explosive demeanor ". Bume frequently criticized Czerwenka's style of play, even calling him a »silly fool«. Since Bume's choleric temper was well known to lead him to frequent outbursts, those who knew him believed they were "not intended as insults« and Czerwenka and Bume were initially on a "friendly footing " despite friction at the card table. With time, however, Czerwenka became more aggrieved. In early September 1906, Czerwenka went so far as to declare in front of other persons that he was not inclined to play at the same table as Bume - a declaration that Bume initially took as a joke. Even when, on the following day, Bume saw that Czerwenka was absolutely serious, he neither demanded ssatisfaction` nor requested an explanation. The two men silently avoided each other not only at bridge but altogether. If Bume approached a game in progress, when the rubber was over, instead of drawing cards to see who would have to make room for him, as was customary, Czerwenka would simply stand up and leave.

At about five o'clock in the afternoon on Sunday, 25 November 1906 - just two weeks after Czerwenka's $26^{\text {th }}$ birthday, Bume entered the game room and found that there was only one game in progress and that Czerwenka was seated at the table. Bume indicated his intention to join the game, but to his surprise, Czerwenka did not immediately leave. Instead, Czerwenka participated in a drawing of cards to see which current player would make room. Bume, »in the presence of multiple other persons", cried out "This is insolence of the highest order! « and - allegedly - threatened »Watch out, I'll box your ears! «102

On the following day, in front of three other members of the club, the insulted Czerwenka challenged Bume to a duel. ${ }^{103}$ Attempts to negotiate an amicable settlement failed "due to the great bitterness of both parties". Czerwenka took advantage of his right as the offended party to determine the weapon and requested a duel with pistols. Bume responded that he would happily engage in a duel with swords, under whatsoever conditions, but head of a company, as well as in consideration of his minor son, who would be otherwise left alone in East Asia, he could not possibly get involved in a duel with firearms «. Czerwenka, on the other hand, alleged that he had been too weakened by extended illness to engage in a sabre duel. "As a consequence of the responses of both opponents, a duel appeared unfeasible and had to be abandoned «, the vice consul later reported.

With no other option, Czerwenka filed a complaint against Bume in the consular court. ${ }^{104} \mathrm{He}$ accused Bume of a "violation against the Assurance of Honor «105 (Sicherheit der Ehre), through verbal insult (Verbalbeleidigung) and the threat of abuse (Drohung mit Misshandlungen). ${ }^{106}$ Czerwenka further requested that Bume be forced to pay the costs of a public announcement of a judgment against him. Far from producing a resolution of the threat against Czerwenka's honor, however, the hearing only gave Bume further opportunity to express his scorn. The judge, Vice Consul Miloslav Kobr, reported that "Theodor Bum [sic] flew into such a rage [in eine derartige Aufregung ... geriet] against the plaintiff, that his behavior nearly caused me to use the fiercest disciplinary measures available«. The defendant admitted to having said "insolence of the highest order «, which was confirmed by two witnesses. He refused to either confirm or deny having made a threat to box Czerwenka's ears. The consular court officially confirmed, beyond doubt: Czerwenka's honor had been insulted.

Not surprisingly, given Bume's behavior during the hearing, the judge was inclined to believe Czerwenka's account of the events and found Bume guilty of violating $\$ 496$ of the State law, which banned "Übertretungen gegen die Sicherheit der Ehre «, by using the phrase "This is insolence of the highest order" and of making threats that suggested his intention to follow up with assault, although it was not definitively proved that he used the specific phrase "Watch out, I'll box your ears". He was sentenced to three days of arrest, a sentence in the middle of the spectrum of possibility. The judge declined to impose the most serious sanction since "although admittedly in the rooms of a Club the expectation of decent behavior is imposed on every man", the Club still did not earn the expectation of the kind of reverential behavior that pertained to a church. A further mitigating circumstance was that Bume's 
outburst had occurred in a moment of "violent emotion " (heftige Gemütsbewegung). "The intense excitability and sensibility of the accused, his violent emotions, and his previously spotless moral conduct were all considered as mitigating circumstances«. On the other hand, however, the defendant's behavior during the hearing only underscored the accusations against him - outbursts such as "fictional misrepresentations!» constituted an aggravating circumstance.

Bume had as little respect for the decision of the consular court as he did for the consular attaché. A Hungarian newspaper covering the story noted with amusement that Bume filed an appeal with the consular appellate court in Constantinople and simultaneously sent all the files related to the entire affair, showing the lieutenant's "retreat " (Retirade) from a duel by sword to the Dragoner regiment where Czerwenka was a reserve officer.

The appellate consular court in Constantinople was less impressed by the severity of Bume's misbehavior, finding it impossible to prove that Bume had made a threat "loudly and in order to be heard by others «. ${ }^{107}$ The appellate court found, moreover, that Bume's behavior in the court was irrelevant to the judgment; he was on trial for insulting Czerwenka's honor, not the judge's. Finally, the appellate court noted that for a man of Bume's social standing, an arrest would have »disproportionately severe consequences«. The appellate court, still finding Bume guilty of having said "this is an insolence of the highest order", fined him 100 Crowns plus court costs. ${ }^{108}$ Hours and hours of inquiry recorded over pages upon pages about a two-minute dispute between a mediocre card player and the local loudmouth.

Czerwenka's reaction to the appellate court's decision is not recorded, but it can hardly have been a happy one. Taking a man to court was not, according to the standards of the time, a satisfactory alternative to resolution by duel. ${ }^{109}$ The Pesti Hirlap published on February 1907 a denunciation of Czerwenka, describing the whole incident as an embarrassment to Austria with a consul "the length of whose title was only exceeded by his empty-headed boasting " playing the starring role. In the Hirlap correspondent's estimation, Bume was an "esteemed older gentleman" and "millionaire wholesaler " and the only one of the two who could possibly emerge from the incident with his honor intact. He had ordered Czerwenka to hold his tongue; he had gallantly agreed to a sabre duel under any conditions Czerwenka cared to impose. Czerwenka, however, although a lieutenant in the reserve with the Dragoners, refused a sabre duel "with the explanation that Mr. Bume is much stronger and that he would thus have no chance against him « - a situation that the Hirlap described as a "Schlamastik" (mess) that could hardly be repaired by a suit in consular court. "It is certain«, wrote the Pesti Hirlap, "that Czerwenka will have to resign his commission - but this is a pathetic bandaid on Austria's severely wounded reputation - at whose cost the local English colony is scornfully amused. ... At home such scandals can be somehow hushed up. But it is an intolerable state of affairs if our ... consular officials stage the most indescribable scandals here, far overseas, where personal and national reputation is a thousand times more valuable». The article called on the Foreign Ministry to ensure that only officials "with better character and irreproachable moral conduct" were sent abroad: "How can we demand that foreigners respect our joint flag if our own offices besmirch it? «110

The Pesti Hirlap expected this incident to end Czerwenka's career, but it did not. Nor did he lose his officer's commission. ${ }^{111}$ Czerwenka's career was cut short not by pride or failure to protect his honor but only by the dissolution of the monarchy itself. Only a few weeks after this incident, in January 1907, he was promoted to vice consul. In 1908, he was sent to the provincial court in Trieste where his "competencies and hard work" were commended and, in recognition of his successful service, he was entrusted with cases involving bankruptcy, assault and battery, property theft, and violations of the assurance of honor. ${ }^{112}$ His specialty. Czerwenka was promptly promoted to consul at age 32. Throughout his career, in Shanghai, Galați, Calcutta, Port Said, Bombay, Bucharest, and Ploesti, Czerwenka's conduct was found to be above reproach. ${ }^{113}$ After the monarchy's collapse, officials in the Ministry applied political pressure to the new President of the Republic to ensure that Czerwenka would be promoted to Consul General II class so that he could receive a higher pension. He lived in Vienna until his death in 1976. 


\section{Maximilian Kutschera ${ }^{114}$}

If Szathmáry Király was an arrogant, belligerent hothead and Czerwenka was a humorless, punctilious expert, then Maximilian Kutschera was a quixotic and unstable but dedicated romantic. Kutschera was born on 19 December 1851 in Vienna. After graduating from the Naval Academy in 1870, he served as a Linienschiffsleutnant in the active navy. He became the shipping director for Bosnia and Herzegovina before asking to be transferred to the consular corps in December 1895. He was reliable, had a »highly respectable disposition" (hochanständige Gesinnung) and "excellent character traits" (vorzüglichen Charactereigenschaften). He was earnest and zealous, well-versed in matters nautical and technical and fluent in German, Italian, French, and English and could speak, although not write, Bosnian.

Kutschera's moral integrity earned frequent praise in his personnel file. He showed, throughout his career, a keen awareness of questions of honor. In May 1899, for example, while stationed as a vice consul in Hong Kong, he warned of a coming day when captains approaching the port of Hong Kong would fire seven cannon shots in his honor, since he was a vice consul, rather than the nine shots to which he was entitled due to his rank in the Navy - a prospect, he warned, that would "make his social position completely untenable « and would have consequences for the empire. "That the monarchy's highest-ranking career official in [Hong Kong] ranks, at official and even social occasions, below the consuls of even the most insignificant states, most of whom arrived later, and some of whom are not very respected, has an unpleasant effect and undermines the prestige of the monarchy «. ${ }^{115}$ The report ran 11 pages.

On 2 September 1906, when Kutschera was 55 years old and had been placed in charge of the consulate in Constanța, he sent an ominous telegram to the Ministry of Foreign Affairs. "Insulted on street by Gradisteanu, President of National League of Transylvania, whereby spectators took part, this evening. Police Chief promised Prefect thorough investigation and satisfaction. Report follows«. The following day, he submitted a full report. As was his habit, he had been taking his dinner in the Hotel Carol, where he lived, when a man (who begun loudly berating a waiter for daring to speak (with an older woman and her daughter, seated at a table near the consul) Hungarian in the middle of Romania. Gradisteanu stormed out of the restaurant, and Kutschera approached the "ladies" to ask if they required "protection «, for which they thanked him.

Later in the evening, Kutschera, together with a Hungarian shipping agent, strolled along the boulevard "where all the world promenades at that hour" and passed by Gradisteanu, who was seated on a bench, several times. Although Kutschera and his companion spoke Hungarian as they passed Gradisteanu, the latter did not object, which Kutschera took to mean "that the courage of his conviction was only applied vis à vis defenseless ladies «. Kutschera's obligation, as a man of honor, was to protect such defenseless ladies. ${ }^{116}$ And so, the next time he passed by Gradisteanu, Kutschera said, in French, »it is cowardly to insult ladies«. Gradisteanu hurried after him, asking if he had something to say, and Kutschera repeated his remark. The two men each demanded the other's name, and a crowd gathered. The choleric Gradisteanu began to shout, and Kutschera offered his card to an officer standing nearby with the remark that Gradisteanu must be a "fool«. Kutschera walked on and stopped further down the promenade to talk with the family of a friend. There he was approached by a crowd of people, Gradisteanu in its center, and as some in the crowd held him back, Gradisteanu screamed indecipherable curses at Kutschera and tried to punch him. Kutschera parried Gradisteanu's blow, but others in the crowd pushed him back and he stumbled. Friends and acquaintances rushed to Kutschera's aid, one calling out that he was a consul; others led Gradisteanu away. The entire incident lasted only a few seconds. Kutschera's friends informed the prefect, who told the chief of police who visited Kutschera that very evening to apologize and promise an investigation. The chief of police informed Kutschera that his unknown opponent was the president of the National League of Transylvania and passionately hated all things Hungarian. In Kutschera's estimation, Gradisteanu was not only not satisfaktionsfähig, he was not even sane (unzurechnungsfähig). Kutschera was nevertheless troubled by the fact that unidentified people from the crowd had also physically assaulted him and expected an official response from Romania. 
From the standpoint of the Austro-Hungarian ambassador, in whose lap all this eventually landed, it was a sticky case, complicated by the fact that Kutschera was actually the one who had insulted Gradisteanu, not the other way around. Kutschera had publicly called Gradisteanu a coward, hours after an incident Gradisteanu may not have either remembered or realized that Kutschera witnessed. Gradisteanu was 70 years old and a Romanian nationalist; it would have been easy enough to declare that he was incapable of giving satisfaction. Kutschera, however, was widely praised in the Hungarian press as a "martyr for his sacrifice on behalf of the Hungarian language«. There was no chance that the matter would quietly fade away. Some resolution was required. Knowing full well that Kutschera was in the wrong and eager to have his honor protected so that he could remain in his post, the ambassador advised him to demand satisfaction of Gradisteanu - and reported that advice (to break the law) to the Ministry. As eager as the ambassador was to protect Kutschera, however, he could not advise the Ministry to commend him for his actions in defense of the Hungarian ladies. "It is undeniable that Kutschera's intent to hold Gradisteanu responsible for his abuses towards the waiter was commendable, but the way in which he took him to task was so ineptly chosen, that both Kutschera and the Romanian government are in an embarrassing position". Where so many men were determined to help Kutschera defend his honor, a solution was quickly found: Gradisteanu had spread the rumor that he had hit Kutschera, whereas Kutschera claimed to have parried the blow; Kutschera could use this slanderous claim as justification for sending seconds to challenge Gradisteanu. Their sworn statement that Gradisteanu refused to provide satisfaction was submitted to the Austro-Hungarian embassy in Bucharest. This, Kutschera's friends hoped, was enough to prove that Gradisteanu was not satisfaktionsfähig after all - and that, as a consequence, the duel that had failed to materialize was not really required. Unfortunately for Kutschera, this was not particularly convincing.

Kutschera's colleagues, friends, and supervisors had done everything they could to support him. They had protected him from physical assault. They had taken his part despite their knowledge that he had waited far too long to confront Gradisteanu. They had joined him in searching for excuses to explain his behavior. They had challenged Gradisteanu when that seemed most favorable to Kutschera's reputation and called him satisfaktionsunfähig, incapable of satisfaction, when that seemed more favorable. But however they tried to describe the incident to themselves and to others, however many Hungarian newspaper articles celebrated Kutschera's patriotism and bravery, there had been no duel, there had been no apology, there was no satisfaction.

Kutschera was undone. Lajos/Ludwig Thallóczy, a Balkan expert, archivist, and administrator in the Finance Ministry (whose exact relationship to Kutschera remains unexplained), reported to the Section Head in the Ministry (Ludwig von Callenberg) that Kutschera "finds himself in a profoundly nervous, agitated condition «, adding that he must be recalled to Vienna: »I myself am a key witness that Kutschera is truly ill«. The ambassador, Szápary, added that Kutschera's condition throughout his entire time in Constanza had been abnormal - taking him back to a time five years earlier when Kutschera had suffered a "shock to the nerves" in Shanghai. Kutschera had been miraculously cured of the "disruption to his nervous system « during a sea voyage, when his steamer hit a typhoon en route to Japan. Ever since the incident with Gradisteanu, however, he had suffered a relapse: "whether the incident with Gradisteanu is the cause or the consequence of his relapse eludes my judgment «. Kutschera's private letters and his behavior during the ambassador's visit left no doubt: he suffered from some "psychic ailment«. Kutschera reported that "feelings of anxiety begin near his heart, rise to his head, everything goes black and he is not in control of his actions". Although they did what they could, Kutschera's colleagues and superiors could not do enough to restore his equilibrium. His mistake was not severe enough to be dismissed as dishonorable. Whether Kutschera's mental instability was the reason he had allowed himself to be humiliated by Gradisteanu or his humiliation had caused his mental instability did not matter. Either way, his career was finished. By the summer of 1907, less than a year after the fateful evening on the promenade in Constanta, he had retired at the age of 56 . 
Trying to estimate, even roughly, the number of duels that were actually fought in nineteenth-century Central Europe would be a fool's errand. ${ }^{117}$ The insults and demands for satisfaction outlined here are remarkable in that none of them involved fatalities - nor even casualties. Most duels that leave evidence in the written record come to our attention because they lead to the death of one of the principles and therefore cannot be quietly ignored. ${ }^{118}$ Presumably, these are only a small proportion of the total. The cases described here all come from the records of the Ministry of Foreign Affairs, and the primary reason they are recorded is because of concern about the correct behavior of consuls as well as the public reaction to their perceived honorable or incorrect behavior, either in foreign countries or in the domestic press. These are not records from the Justice Ministry; they do not concern the prosecution of men who openly flout the laws banning duels. They are records from the consuls' personnel files, created in order to justify their actions to their superiors.

Ute Frevert's comment about the bourgeoisie in general applies particularly to the civil service: "That citizens sought to settle their disputes or conflicts of interests by use of force did not seem to fit into the concept of bourgeois society acting in a rational and disciplined manner «. ${ }^{119}$ These files show how consuls could make the "use of force" professional by codifying the exact conditions in which rage and its resolution become rational. Norbert Elias called the duel "an open violation of the state's monopoly on violence, the last refuge of an upper class (Oberklasse) that resolved its own personal affairs according to rules that its members had created themselves and that only applied to the privileged class (Schicht) «. ${ }^{120}$ In the case of these consuls, state representatives adjudicated which kinds of violence qualified for special privilege. The men in these consulates - and, to a certain extent, their superiors back at the Ministry of Foreign Affairs formed what Barbara Rosenwein has called an »emotional community", that is a community that not only enforced the rules by punishing those who did not conform but also supported its members in trying to find ways to conform when it was not always easy to do so. The bureaucracy of honor suggests that the regulation of insult, honor, and satisfaction was less a challenge to the state's monopoly of force than an essential aspect of its inner life. Each of these cases revealed a contradiction at the center of the bureaucratic management of honor. The consular official, an imperial bureaucrat, earned the respect of imperial subjects because of his rationality and impartiality, his cool, calm, and collected dispatch of imperial business without bias or passion. Yet, to resolve an insult and maintain his honor, he was obliged to react with strong emotion, with an irrepressible demand for justice. In this, he could count on support. The same institutional structure that compelled consuls to safeguard their honor also bolstered it. 
1 The author thanks Susanne Bauda, Peter Becker, Holly Case, István Deák, Robert Garot, Walter Johnson, Derek Penslar; the Institut für die Wissenschaften vom Menschen in Vienna; Stefan Nellen and the Schweizerisches Bundesarchiv in Bern; the Harvard Library; Gerhard Gonsa and the Haus-, Hof- und Staatsarchiv in Vienna; and Emily Shea and the Kickstand Reading Room.

2 Eduard Schikaneder: "Die Zauberflöte«, 1791. One English version reads: "No fear of death shall stop me acting like a man, / continuing to follow the path of virtue. / Open the gates of terror for me«.

3 »It is my duty to face him as a friend». (»Es sei meine Pflicht, ihm als Freund und nicht als Feind entgegenzutreten, und Gesandtschaft und Konsulat sollen gemeinsam im Intereße des Dienstes harmonisch zusammenwirken«). Ernst Ritter Schmit von Tavera: Petropolis, Brazil, to Ministry of Foreign Affairs, Wien, 3. 3. 1895. Österreichisches Staatsarchiv [ÖStA], Haus-, Hof- und Staatsarchiv [HHStA], Ministerium des Äußern [MdA], Administrative Registratur [AR] Fach [F] 4, Karton 164.

4 Engelbert Deusch called each consulate a Tintenburg or »red-tape factory“, Engelbert Deusch: Die effektiven Konsuln Österreich (-Ungarns) von 1825-1918. Ihre Ausbildung, Arbeitsverhältnisse und Biografien, Wien u. a. 2017, p. 122.

5 According to its website, the Haus-, Hof- und Staatsarchiv "comprises 16,000 linear metres of shelves with 130,000 account books and filing boxes, 75,000 acts and charters, 15,000 maps and plans, as well as about 3,000 manuscripts«. Österreichisches Staatsarchiv, "Haus-, Hof- und Staatsarchiv - Information in brief", online: http://www.oesta.gv.at/site/6150/default.aspx (14. 8. 2018). Consular service records represent only a small portion of the archive's holdings.

6 On the emperor's processing of paperwork, see Stefan Kray: Im Dienste der Kabinettskanzlei während des Weltkrieges, Budapest 1937, pp. 76-78. On the vast increase in the volume of correspondence to be managed in mid-nineteenth century Britain, see David Vincent: The Culture of Secrecy. Britain: 1832-1998, Oxford 1998, pp. 30-32.

7 HHSTA, MdA, AR, F 8 - 256, Kaiserliche Konsulate und Agentien, Konsularsitze W, Y (Winnipeg, Yokohama) and 257 Kaiserliche Konsulate und Agentien, Konsularsitze Y, Z (Yokohama, Zanzibar).

8 ÖStA HHStA MdA AR F 34, Sonderreihe 90, Handelspolitische Akten Rubrik 48: Sklavenhandel.

9 The larger book project has not yet been published, but some of the results of the research can be found in Alison Frank: "The Children of the Desert and the Laws of the Sea. Austria, Great Britain, the Ottoman Empire, and the Mediterranean Slave Trade in the Nineteenth Century«, in: The American Historical Review 117 (2012), pp. 410-444.

10 »Gefühle als geschichtsmächtige Kategorie: Ingrid Bauer und Christa Hämmerle im Gespräch mit Ute Frevert», in: L'Homme: Europäische Zeitschrift für feministische Geschichtswissenschaft 24/1 (2013), pp. 109-118, at p. 112: „Feelings are, after all, shared, communicated, they structure relationships between people and create 'Gemeinschaft،, in part also 'Gesellschaft،, in the positive and negative sense. Above all, emotions guide actions«.

11 Josef Zipser, a Viennese attorney, requested Czerwenka's working address and salary on behalf of Miss Jeanne Hammant, who declared herself to be the mother of his illegitimate child. The Ministry confirmed that Czerwenka was a consular attaché in Shanghai, but refused to provide information about his salary without a court order. Z. 37634/10, 22. 5. 1905.

12 When Maximilian Kutschera requested permission to marry Agnes Schleifer, the Ministry wrote to the Bezirkshauptmannschaft St. Pölten and then the Viennese Polizeidirektion requesting "confidential and as inconspicuous as possible inquiries" (»vertrauliche und möglichst unauffällige Erhebungen«). HHStA AdReg 4, 184, Kutschera. The MdA's Erlass vom 2. 5. 1899 , Z. $24.487 / 10,1899$, required that all career consular officials get permission before a marriage. The MdA would consider the "financial circumstances" and "social position of the bride" and ensure that there was »nothing that would make the proposed marriage impermissible due to serious professional considerations«. One or both parties had to have an annual income of K 2000 for consuls, K 4000 for viceconsuls. Josef Malfatti di Monte Tretto: Handbuch des österreichisch-ungarischen Konsularwesens 1, Konsularwesen, Wien 21904, pp. 75-76. Regulations related to marriage dating back to 1850 are also covered in Deusch: Die effektiven Konsuln, pp. 92-94. These terms compare favorably to the "Kaution" that a career lieutenant's chosen bride would have to produce: 60,000 Kronen in 1910, the equivalent of 50 years of pay! István Deák: "Chivalry, Gentlemanly Honor, and Virtuous Ladies in AustriaHungary«, in: Austrian History Yearbook 25/1 (1994), pp. 1-12, at p. 12.

13 On 26. 8. 1907, Waldemar Czerwenka requested permission to marry Marietta Regenhart, whose mother promised the required dowry. On 6. 10. 1907, the Vienna police reported that the family was "prosperous and enjoys a good reputation. Impeccable deportment, meticulous education«. Without having seen that report or providing any reasoning, Czerwenka withdrew his request to marry Regenhart on 14. 10. 1907. ÖStA HHStA MdA AR F4 - 65, Personalia Cze-Czu, Czerwenka [henceforth F4_65], Z. 81267 pr 21.10.1907 and Z 78506/10.

14 Ute Frevert: Emotions in History. Lost and Found, Budapest 2011, p. 45.

15 There are, of course, other precedents for the corporate relevance of personal honor - the most obvious being the hopes of some early central European Zionists that dueling could be used as wan assertion of masculine and national honor . Derek Penslar: Jews and the Military. A History, Princeton 2013, p. 75.

16 Patrick Joyce: The State of Freedom. A Social History of the British State since 1800, Cambridge 2013, p. 193 (emphasis added).

17 The book was written during the four-year period where Jhering taught law at the University of Vienna (1868-1872). Rudolf von Ihering: Der Kampf um's Recht, Wien 1872, pp. 95-96.

18 Other historians have investigated multiple other ways in which civil servants in practice "failed" to live up to the expectation of the complete erasure of their partialities, politics, and personal prejudices. See, for example, Peter Becker: »Recht, Staat und Krieg. `Verwirklichte Unwahrscheinlichkeiten in der Habsburgermonarchie«, in: Administory 1 (2016), pp. 29-30, online unter: https://doi.org/10.2478/ADHI-2018-0003 (4. 9. 2018).

19 Frevert: Emotions, p. 44.

20 Andrew Mills points out that the insulted party demands "Satisfaktion«, not "a duel«. Andrew Mills: "Satisfaktion in Nineteenth Century German Dueling Violence and Its Relevance for Literary Analysis«, in: The Germanic Review 86 (2011), pp. 134-152, insb. p. 134-140.

21 Frevert: Emotions, p. 10, pp. 64-65. „Honor no longer plays much part in our thinking«. Frank Stewart: Honor, Chicago 2010, p. 9.

22 Frevert: Emotions, p. 41. Historian Victor Kiernan, in a lengthy monograph on dueling, used »to relieve their feelings" as a euphemism for "to fight a duel«. Victor Kiernan: The Duel in European History. Honour and the Reign of Aristocracy, Oxford 1988 [London 2016], p. 293.

23 Julian Pitt-Rivers: »Honour and Social Status», in: Jean G. Peristiany (ed.): Honour and Shame. The Values of Mediterranean Society, 
Chicago 1966, pp. 19-77; Julian Pitt-Rivers: »Honor «, in: David L Sills (ed.): International Encyclopedia of the Social Sciences 6, New York 1968, pp. 503-511; Stewart: Honor; Jean G. Perstiany / Julian PittRivers: Honor and Grace in Anthropology, Cambridge 1991, p. 6; Geoffrey Best: Honour among Men and Nations. The Transformation of an Idea, Toronto 1982; David Gilmore: »Introduction. The Shame of Dishonor «, in: David D. Gilmore (ed.): Honor and Shame and the Unity of the Mediterranean, Washing DC 1987, pp. 2-18; Carolyn Strange / Robert Cribb / Christopher Forth (ed.): Honour, Violence and Emotions in History, London 2014.

24 Henderson: »Honor«, p. 13. Pieter Spierenburg emphasizes a tripartite division that is also favored in some of Pitt-Rivers' work: "honor has at least three layers: a person's own feeling of selfworth, this person's assessment of his or her worth in the eyes of others, and the actual opinion of others about her or him«. Pieter Spierenburg: "Masculinity, Violence, and Honor. An Introduction«, in: Pieter Spierenburg (ed.): Men and Violence. Gender, Honor, and Rituals in Modern Europe and America, Columbus, $\mathrm{OH} 1998$, pp. 1-36, at p. 2.

25 Henderson: »Honor«, pp. 9-29.

26 Kwame Anthony Appiah: The Honor Code. How Moral Revolutions Happen, New York 2010, p. 16, 20, 209.

27 Jan Plamper: "The History of Emotions. An Interview with William Reddy, Barbara Rosenwein, and Peter Stearns", in: History and Theory 49 (2010), pp. 237-265, at p. 242.

28 Plamper: »The History of Emotions«, p. 243. The classic example is Arlie Russell Hochschild's study of flight attendants whose professional security depended on the ability to be ever cheerful. Arlie Russell Hochschild: The Managed Heart. Commercialization of Human Feeling, Berkeley, CA 1983.

29 "Çe ne sont ni les balles ni les épées qui tuent: çe sont les témoins«. Charles du Verger de Saint-Thomas: Nouveau Code du Duel. Histoire, Legislation, Droit Contemporain, Paris 1879, p. 206. Istvan Deák offers a slightly different translation, Istvan Deák: Beyond Nationalism. A Social and Political History of the Habsburg Officer Corps, 1848-1918, New York 22010, p. 135.

30 A career officer was a »man of honor by profession « (Ehren-Mann aus Profession), Ute Frevert, "Der >Louisı - oder was den Mann zum Manne macht: Assessor Ernst Borchert sucht seine Satisfaktion«, in: Uwe Schultz (ed.): Das Duell: der tödliche Kampf um die Ehre, Frankfurt am Main 1996, p. 400.

31 Deusch: Die effektiven Konsuln, p. 61. On the creation of the one-year volunteers, see Johann Christoph Allmayer-Beck: "Die bewaffnete Macht in Staat und Gesellschaft«, in: Adam Wandruszka (ed.): Die Habsburgermonarchie 1848-1918, Bd. 5, Die bewaffnete Macht, Wien 1987, pp. 75-76.

32 Deák: Beyond Nationalism, p. 87, 132. Gunther Rothenberg calculated that only 35 percent of one-year volunteers who sat for the examinations between 1869 and 1885 qualified for a lieutenant's commission. Gunter Rothenberg: The Army of Francis Joseph, West Lafayette, IN 1998, p. 83.

33 By »German lawyers«, Stewart means lawyers who wrote in German. Stewart: Honor, p. 1.

34 Deák cites several published in Austria-Hungary: Ludwig Berger: Der Waffengebrauch des Offiziers. Ein Orientierungsbehelf, Linz 1898 [1903]; Franz von Bolgar (ed.): Regeln des Duells, Wien 1882 (with many editions in many languages); Gustav Hergsell: Duell-Codex, Wien u. a. 1891; Friedrich Teppner: Duell-Regeln für Offiziere und Nachschlagebuch in Ehrenangelegenheiten, Graz 1898. Also: Josef Bartunek: Die Austragung von Ehrenangelegenheiten. Ein Beitrag zur zeitgemässen Lösung der Satisfaktionsfrage, Wien 1912; Josef Burian:
Der kaiserlich-königliche Oesterreichische Offizier. Systematische Darstellung der Pflichten, Rechte, Ansprüche und Gebühren der Offiziere im Allgemeinen, sowie der Obliegenheiten mit Bezug auf die Dienstsphäre im Besondren, 3 Bde., Prag 1860; Dienstverkehr des Reserveoffiziers. Instruktionsbuch für Reserveoffiziersschulen, 10. Teil, Wien 1915; Alexander Hajdecki: Officiers-Standes-Privilegien. System und Praxis des geltenden Officiersrechtes der k. u. k. bewaffneten Macht, Wien 1897; August Kielhauser (ed.): Die Vorschrift für das ehrenrätliche Verfahren im k. u. k. Heere und Ehrenratsfragen, Wien 41914; Karl Friedrich Kurz (ed.): Militär-Taschen-Lexikon 1, Wien 101911, insb. Abs.: »Ehrenangelegenheiten«; [Captain] Adalbert Schneider: Der Officier im gesellschaftlichen Verkehr, Graz ${ }^{31895}$; Vorschrift für das ehrenrätliche Verfahren im k. u. k. Heere, Wien 1908; Vorschrift über die Behandlung unverbesserlicher Offiziere, Wien 1862. István Deák: „Chivalry«, p. 2. On »emotionology«, see Jan Plamper: »The History of Emotions«, p. 262.

35 Deák's study of the officer corps offers examples of officers being compelled "to overreact to all manner of insults and slights « and to take extreme and violent measures to protect their honor. Deák, Beyond Nationalism, pp. 126-138.

36 Deák: Beyond Nationalism, p. 130. The emperor once refused the appeal of a nobleman who wanted to return to Austria after a few months of self-imposed exile after killing his opponent in a duel not because the man had broken the law but because he had openly sided with Prussia during the Austro-Prussian war of 1866. Vortrag des (Ungarischen) Justizministers über das Ah. Bezeichnete Gesuch des wegen Zweikampfes mit dem Grafen Nemeš und Tödtung des Letzteren steckbrieflich verfolgten und flüchtig gewordenen Karl Fürsten Lichnowsky um Ag. Gestattung der straffreien Rückkehr nach Österreich, 15. 9. 1867, No. 1367, summary, No. 3569, 17. 9. 1867. Thanks to Susanne Bauda for drawing this case to my attention.

37 Leo XIII.: Pastoralis Officii. Encyclical of Pope Leo XIII on the Morality of Dueling, 12. 9. 1891, online: http://w2.vatican.va/content/leo-xiii/ en/encyclicals/documents/hf_I-xiii_enc_12091891_pastoralis-officii. html (1. 8. 2018). On the Catholic Church's opposition to dueling, see Hubert Mader: Duellwesen und altösterreichisches Offiziersethos, Osnabrück, 1983, pp. 119-128.

38 Peter Gay: "Mensur: The Cherished Scar «, in: The Yale Review 80 (1992), pp. 94-121, at p. 107; Frevert: Emotions, p. 47f.; Thomas Weber: Our Friend, "the Enemy«. Elite Education in Britain and Germany before World War I, Stanford, CA 2008, p. 106.

39 At the founding session of the Anti-Dueling League, a motion to prohibit all members from engaging in duels themselves was defeated. Gay: »Mensur«, p. 101.

40 A Veteran Diplomat, "Checking the Duel in the High Life of Europe: The Embarrassing Position of American or British Diplomat Who Is Challenged to Fight a Duel«, The New York Times, 23. 8. 1908: SM6.

41 »Checking the Duel«, SM6.

42 »durch Anführung nichtiger Vorwände und unberechtigter Voraussetzungen in feiger Weise dem Zweikampfe ausgewichen sei, die Standesehre verletzt«. Mader, Duellwesen, p. 126, discussing the case of Lieutenant Anton Marquis Tacoli.

43 Deák: Beyond Nationalism, p. 131.

44 "Consulates« here includes general consulates, consulates, vice consulates, and agencies, both those staffed by career civil servants and those headed by »honorary« consuls, vice consuls, etc. Deusch: Effektiven Konsuln, p. 21.

45 Joseph Piskur: Oesterreichs Consularwesen, Wien 1862, p. 31.

46 Piskur: Oesterreichs Consularwesen, pp. 14-15.

47 On the aristocracy's control over the foreign service, see William Godsey: "Quarterings and Kingship. The Social Composition of the 
Habsburg Aristocracy in the Dualist Era«, in: Journal of Modern History 71 (1999), p. 59; William Godsey: Aristocratic Redoubt. The Austro-Hungarian Foreign Office on the Eve of the First World War, West Lafayette, IN 1999.

48 Of the 617 »career « consuls profiled in Deusch's recent encyclopedic account, 272 graduated from the Oriental (Consular) Academy and 227 had university degrees. Deusch: Effektiven Konsuln, p. 9.

49 See, for example, the complicated biography of Laurenz Szapáry von Szápár. Deusch: Die effektiven Konsuln, pp. 644-645.

50 Deusch: Die effektiven Konsuln, p. 53. "Service rules and proper conduct (Anstandslehre) « was part of the curriculum of the cadet schools. Deák: Beyond Nationalism, p. 89.

51 Piskur: Consularwesen, p. 37.

52 A French consular manual from 1850 lamented, "The consular institution, which affects the greatest commercial interests, is still today, among all the branches of public administration in France, the one which is the least known, consequently the least appreciated, the most neglected «, Louis-Joseph-Auguste de Moreüil: Manuel des agents consulaires français et étrangers, Paris 1850, p. 3, cited in Mathieu Jestin: »Building a Local Administration Abroad. The French Consulate in Salonica in the Nineteenth Century", in: Administory 2 (2018), p. 68, online: https://doi.org/10.2478/ADHI-2018-0016 (4. 9. 2018). Desmond C. M. Platt's history of British consuls since 1825 holds an argument about their status in its very title; he lists markers of the symbolic and material inferiority of consuls on page 2. Desmond C. M. Platt: The Cinderella Service. British Consuls since 1825, New York 1971

53 Max Weber: »The Technical Superiority of Bureaucratic Organization over Administration by Notables«, in: Guenther Roth / Claus Wittich (ed.): Max Weber: Economy and Society. An Outline of Interpretive Sociology, Berkeley, CA 1978, p. 975.

54 »Anständiges Benehmen gegen Parteien und Strenge Unparteilichkeit«, Malfatti: Handbuch, p. 90.

55 Vincent: Culture of Secrecy, p. 31.

56 Joyce: State of Freedom, p. 194. Peter Becker consequently encourages historians to consider the technological apparatus of bureaucracy to be equally important to the functioning of authority as the "social background, education, career patterns, attitudes, mental horizons, and actions « of civil servants. Peter Becker: "Sprachvollzug. Kommunikation und Verwaltung», in: Peter Becker (ed.): Sprachvollzug im Amt. Kommunikation und Verwaltung im Europa des 19. und 20. Jahrhunderts, Bielefeld 2011, p. 29.

57 Czerwenka. Z. 31937/10 pr. 2.V.1906, from General Consulate Shanghai 27. 3. 1906 to Ministry of Foreign Affairs.

58 Szathmáry Király. Z. 3098 pr. / 7 u. 10; 07. 2. 1887, No. 16/res from Heidler-Egeregg, Bucharest, 05. 2. 1887, to MdA.

59 Piskur: Consularwesen, p. 38.

60 Quoted in Vincent: Culture of Secrecy, p. 35.

61 Piskur: Consularwesen, p. 64.

62 Listed in Deusch as Dominik Király von Szathmár. Deusch: Die effektiven Konsuln, p. 382. All references to archival materials related to Szathmáry Király come from his personnel file: HHSTA, MdA, AR, Fach 4, Karton 164.

63 »rechthaberisches und unverträgliches Wesen«, Belgrade, 9. 11. 1888, Z CXXX/9443 [MdA] Z. 27706/10 Pr 11.XI.1888.

64 In Bucharest and Sofia.

65 From Belgrade and from Buenos Aires.

66 In Galați, in Cairo, and in Yokohama.

67 From Galati.

68 See the second epitaph to this contribution.

69 On the importance of the physical layout of the office in accentuating the bureaucrat's privileged position, see Becker: »Sprachvollzug«, p. 10.

70 For an analysis of the importance of the nose, specifically, to a Southern gentleman's honor, see Kenneth P. Greenberg: »The Nose, the Lie, and the Duel in the Antebellum South «, in: American Historical Review 95 (1990), pp. 57-74.

71 "Ich bedauere aufrichtig, daß ich Matsek Unrecht gethan und denselben beleidigt habe, ich bedauere aber noch mehr, und bitte mir gestatten zu wollen, diesbezüglich meine aufrichtigen Gefühlen Ausdruck zu geben, daß ich durch diesen Vorfall das Ansehen und die Würde meiner amtlichen Stellung verletzt habe« (emphasis in original).

72 Carl von Boleslawski: 20. 3. 1886, No. 16/res, "In Betreff des Untersuchungs-Angelegenheit gegen den hieramts in Verwendung stehenden k. u. k. Vice-Consul Herrn von Szathmáry Király. »Protocol«, 4. 3. 1886.

73 Sectionschef von Szögyény: Protocol Nr. 7516, 6. 4. 1886, Wien. It is worth noting the difference implied by using "Schutzbefohlene« or "ward», rather than »client». Compare to Becker: "Sprachvollzug», pp. 9-34.

74 Charles Kingsley, cited in Vincent: Culture of Secrecy, p. 37.

75 J. Millar, The Gentleman's Handbook of Etiquette, cited in Vincent: Culture of Secrecy, p. 40.

76 Depictions of the consuls' uniforms are provided in Malfatti: Handbuch.

77 »Pardon, Monsieur, la voiture était occupée pour moi, comme vous l'avez vu«. Report 1/res, from Ritter von Heidler-Egeregg, Bucharest, to $M d A$, Wien, 9. 1. 1887, Attachment $» F$ «, Szathmáry Király's statement. Henceforth »Szathmáry Király, January 1887 Statement«.

78 Attachment "C«, Protokoll, Bucharest, 7. 1. 1887. The detailed description of the Porter's reaction comes from a statement gathered from Andreas Szabo, the omnibus cab driver for the Union Hotel. All witnesses agreed that the porter warned the gendarmerie off. The chargé d'affaires did not consider the omnibus driver's testimony to be entirely reliable, however: "Bei dessen äußerst niederer Bildungsstufe und Erregtheit, und bei dem Umstande, daß mehreren Détails seiner Aussage von Herrn v. Szathmáry selbst widersprochen wird, habe ich von dessen Beeidigung abgesehen«. Heidler Report 1/res to Graf von Kálnokey, 9. 1. 1887.

79 Consuls did not enjoy the diplomats' absolute immunity from prosecution, but host states often conceded the right to prosecute consuls for transgressions to their home states. Piskur: Consularwesen, pp. 60-63.

80 "Monsieur, vous me devez satisfaction, je vous prie, donnez-moi votre nom « and "e ne vous donne pas de satisfaction, je ne vous dis pas mon nom«. Szathmáry Király, January 1887 Statement. Ute Frevert analyzes a duel between a Prussian civil servant (an assessor in Königsberg) and a lieutenant, in 1896, and finds that the lieutenant was remarkably reluctant to respond to the civil servant's increasingly pointed insults - the civil servant, who felt himself insulted first by the lieutenant, was eager for the duel and the lieutenant was not (»um diese Anerkennung, deren höchster Ausdruck der Zweikampf war, kämpfte der Assessor mit allen Mitteln«). Frevert says this is because a duel with an officer as an opportunity to gain social status - that is, to cement his own status as a man of honor and thus »ebenbürtig" with the lieutenant. The lieutenant, in contrast, had nothing to gain. Szathmáry Király may have had so much trouble extracting a duel from the major not because the major did not care about his own honor but because he did not immediately recognize in Szathmáry Király, in mufti, as an equal. This implicit distinction could not be allowed to stand. Frevert: »Der >Louis«", p. 401. 
81 For a brief biography of Suzzara, see Deusch: Die effektiven Konsuln, pp. 642-643.

82 On sabers vs. pistols, see Frevert: »Der >Louis««, p. 390.

83 »Beide Gegner haben sich nach dem Duelle nachdem die Sekundanten constatirt hatten, daß der Ehre Genüge geleistet worden sei, die Hand gereicht und umarmt«.

84 »Bei diesem Anlaße hat Major Lazaresco bereitwilligst erklärt, daß die von ihm ausgegangene Insulte, nicht dem k.k. Vize Consul und Reserveoffizier Herrn von Száthmary den er gar nicht gekannt habe, sondern einer inm ganz fremden Person galt«.

85 Spierenburg: »Masculinity«, p. 9. »All precautions taken were meant to deflate the situation and allow for detached, polite and scivilized behavior«. Frevert: »Emotions«, pp. 56-57.

86 According to Ute Frevert, waiting to apologize until after the duel was expected of men of honor. Frevert: "Der >Louis«", pp. 392-393.

87 Suzzara's report, Attachment »E«.

88 "It is important to maintain the principle of the question of honor, a certain guarantee against crude violence». "Goethe über das Duell, 9. 8. 1827«, in: Carl A. H. Burkhardt (ed.): Friedrich Müller: Goethes Unterhaltungen mit dem Kanzler Friedrich v. Müller, Stuttgart 1870, p. 115.

89 Frevert: »Der >Louis«", p. 392.

90 Suzzara's report.

91 Frevert: Emotions, p. 46. Emphasis added.

92 HHSTA, MdA, AR, Fach 4, Karton 65.

93 Waldemar Czerwenka was born on 09. 11. 1880 in Piatra in Moldavia, but his family had relocated to Czernowitz by the time he was baptized nine months later. His father, Karl Czerwenka, was the local Factory Manager for the Joint-Stock Company for Lumber and Steam Sawmills and was stationed in Czernowitz most likely in connection with the construction of the Lemberg-CzernowitzJassy Eisenbahn. Baptismal record, 19. 8. 1881. Karl Böhmerle (ed.): Centralblatt für das gesammte Forstwesen 18 (1892), Wien 1892, p. 385.

94 C. Tumlirz: Jahresbericht des Ober-Gymnasiums in Czernowitz, Czernowitz 1894, p. 57.

95 Beilage zu Adm. Ber. No XV ex 1905, from K. u. K Oesterr.-Ung. General-Consulat, Shanghai, to MdÄ, 14. 2. 1905, HHStA F4.

96 Letter from Czerwenka to MdÄ, 26. 5. 1906.

97 Bridge habit: Kobr's Bericht, 5. 4. 1907. Beilage ad Bericht No. 11 Res, Shanghai, 5. 4. 1907.

98 Arnold Wright (ed.): Twentieth Century Impressions of Hongkong, Shanghai, and other Treaty Ports of China. Their History, People, Commerce, Industries, and Resources, London 1908, p. 388.

99 Christian Henriot: »The Shanghai Bund in myth and history. An essay through textual and visual sources", in: Journal of Modern Chinese History 4 (2010), pp. 1-27. According to photographer, minister, and Shanghai resident Charles E. Darwent's 1904 guidebook to Shanghai, the Shanghai Club was »the one club in Shanghai ranking with the best at home. There are all the appointments of a first-class club - two large dining-rooms and private ones, two billiard-rooms, card-rooms, library of 16,364 books, bar, oyster bar, reading-room, kitchen on the top storey«, Charles E. Darwent: Shanghai, Shanghai 1904 , p. 10.

100 Otto Friedländer: Letzter Glanz der Märchenstadt. Das war Wien um 1900, Wien 1969, p. 74. In Waltraud Heindl, Josephinische Mandarine: Bürokratie und Beamte in Österreich Band 2: 1848 bis 1914, Wien 2013, p. 27. Contemporary writers who said lieutenants were underpaid complained that they were »under psychological pressure to senjoy life« «; their basic costs included »membership in the officers' casino«, Deák: Beyond Nationalism, p. 120, »enjoy life« quoted from Salvator R. [recte Rudolf Hetz]: Die Verschuldung unseres Offizierskorps. Ihre Ursachen und Konsequenzen, Wien 1911, pp. 7-9, 49.

101 Joyce: State of Freedom, p. 199.

102 "Das ist eine Frechheit in der höchsten Potenz" and "Passen Sie Auf, Sie werden eine Ohrfeige kriegen«. Ad 37098/10; Abschrift Nr. 2345/1906; Urteil des Generalkonsulates Shanghai.

103 Normally, the challenge and the negotiations over weapons would have been carried out by seconds. The description of these events comes from Vice Consul Kobr's report; Kobr does not mention any seconds and refers only to Czerwenka and Bume. For the two men to have directly debated the use of swords or pistols would have been highly irregular - indeed, according to an interview with István Deák (26. 6. 2018), unheard of.

104 Austria-Hungary was one of 18 or so foreign powers that had treaties establishing concessions in China, including the right of citizens of those foreign powers to be tried under the jurisdiction of their home country. Although Great Britain and the United States had independent court systems in China, both operating out of Shanghai, Austria-Hungary was one of many countries that operated consular courts and relied on the staff of the consulates, with or without any legal training to speak of, to preside over those courts. F.E. Hinckley, »Extraterritoriality in China», in: The Annals of the American Academy of Political and Social Science 39/1 (1912), p. 97f.; Malfatti: Handbuch, pp. 475, 504. On the political philosophy about international relations that undergirded instructions for the functioning of these courts, see Holly Case: »The Quiet Revolution. Consuls and the International System in the Nineteenth Century", in: Timothy Snyder / Katherine Younger (ed.): The Balkans as Europe. 1821-1914, Rochester, NY 2018, pp. 114-115.

105 Thanks to John Hamilton for suggesting this translation of "Sicherheit der Ehre».

106 Joseph Sonnenfels defined "Sicherheit der Ehre« as "der Zustand, worinnen man für seine Ehre nichts zu befürchten hat. Die Ehre, wie sie genommen wird, ist die Achtung von der Rechtschaffenheit eines Bürgers. Der Verlust dieser Achtung ist mit wichtigen Folgen verknüpft«. Joseph von Sonnenfels: Grundsätze der PolizeiHandlung und Finanz, F. X. von Moshamm (ed.), Tübingen 1820, p. 155. James Whitman has analyzed the ways in which the regulation of respect continues in postwar France and Germany and connects the regulation of hate speech in postwar Europe not so much to the lessons learned from genocide as to a longstanding tradition of disallowing »insult«, now interpreted to include »racial sinsult«". James Q. Whitman: »Enforcing Civility and Respect. Three Societies«, in: Yale Law Journal 109/6 (2000), pp. 1282-1284, at p. 1296. "Personal honor « remained inviolable in postwar Germany. Eric Stein: "History against Free Speech. The New German Law against the >Auschwitz - and Other - 'Liesı", Michigan Law Review 85/2 (1986), p. 278. Citing Grundgesetz [GG] art. 5(2), English translation from The Basic Law of the Federal Republic of Germany (1977). Insult (Beleidigung) is prohibited in the postwar Republic of Austria, online unter: https://www.ris.bka.gv.at/GeltendeFassung. wxe?Abfrage=Bundesnormen \&Gesetzesnummer=10002296 (01. 8 . 2018)

107 The president of the imperial-royal (k. k.) Austrian and Royal Hungarian Consular Superior Court in Constantinople was Stephan Kvassay v. Kvassó und Brogyan. Malfatti: Handbuch, p. 478; Hofund Staats-Handbuch der österreichischen-ungarischen Monarchie für das Jahr 1907, Wien 1907, p. 269.

108 At this time, Czerwenka, as the lowest ranking official in the consulate, earned just over 500 crowns a month. 
109 Frevert provides examples of men who insisted on dueling even after a court case had been won. "It was not enough to take the offender to court and have him convicted for slander and libel«. Frevert: Emotions, pp. 45, 47. Andrew Jackson asked van Buren to pardon a man who had been arrested for assaulting him, following the advice of his mother, sindict no man for assault and battery, or sue him for slander « because those injuries could only be repaired by an attack on the body of the injurer. Greenberg: »The Nose«, p. 73.

110 »Osztrák smegrovási kalandokı Shanghaiban«, Pesti Hirlap 10. 2. 1907, p. 35. A translation of the article in German is in Czerwenka's file.

111 Career officers in the army often suffered from their lack of skill in sword-fighting, compared with nationalist student fraternities, and as a result, the army condoned the substitution of smooth-bore pistols for swords in duels, even though the former were far more deadly. Deák: Beyond Nationalism, p. 134.

112 Letter from Oberlandesgerichtspräsidium, Trieste, to k. k. Justizministerium, Z 86776/10.

113 Folder »Dienstbeschreibung«.

114 HHSTA, MdA, AR, Fach 4, Karton 184.

115 Kutschera, 8. 5. 1899, Z. 33809/10 pr 13.VI.1899.

116 Deák: „Chivalry«, p. 8.

117 »Because of their enforced secrecy, no one knows their number even approximately«. Deák: "Chivalry«, p. 12. McAleer does estimate that only about one percent of duels fought in AustriaHungary were fatal. Kevin McAleer: Dueling. The Cult of Honor in Fin-de-Siècle Germany, Princeton 1994, p. 224, Fn. 43.

118 Frevert notes that only a death left a written record: "Wäre es [a particular duel] unblutig zu Ende gegangen, wäre es der Nachwelt vermutlich verborgen geblieben. Nur der Tod Seidenstickers [one of the principals] machte es aktenkundig. Nur so fand es eine schriftliche Überlieferung in den Archiven der preußischen Justizbehörden«. Frevert: "Der >Louis«", p. 394. Kiernan suggests that the inconsistency of meting out punishments may have led to a general disrespect for the law; Kiernan: The Duel, pp. 296, 301.

119 Ute Frevert: "The Taming of the Noble Ruffian. Male Violence and Dueling in Early Modern and Modern Germany«, in: Pieter Spierenburg (ed.): Men and Violence. Gender, Honor, and Rituals in Modern Europe and America, Columbus, OH 1998, pp. 37-63, at p. 48.

120 Norbert Elias: Studien über die Deutschen. Machtkämpfe und Habitusentwicklung im 19. und 20. Jahrhundert, Frankfurt am Main 1989 [2005], p. 79. 


\section{Abstract}

I use the personnel files of three consuls in the AustroHungarian foreign service to consider the ways Habsburg bureaucracy recorded the emotional lives of civil servants. Consuls were expected to interact with Habsburg subjects and other civilians dispassionately and objectively. But conflicts that occurred in their 'free time,' outside the consulates, spilled over into their professional time. The resolution of those conflicts involved their colleagues in the consulates and administrators in Vienna. While showing emotion in interactions inside the consulate was frowned upon, responding to attacks on personal honor with the strongest of emotions was expected of an Austro-Hungarian "gentleman." Consuls had to abide by both the standards of their profession and the standards for "men of honor" (Ehrenmänner) that had been codified with the officer corps in mind. The recognition that both roles were compatible shows the repackaging of certain kinds of "emotion" as professional requirements, rather than excesses.

\section{About the Author}

Alison Frank Johnson is Professor of History and of Germanic Languages and Literatures at Harvard University. She is currently working on a book on Austria Hungary's maritime empire, in which consuls played a leading role. Previous publications include "The Children of the Desert and the Laws of the Sea: Austria, Great Britain, the Ottoman Empire, and the Mediterranean Slave Trade in the Nineteenth Century," which appeared in the American Historical Review in 2012. Other pending works will address the abolition of the death penalty in Austria and the life of the Austrian "Robin Hood," Johann Georg Grassl. 